\title{
Inovasi Kebijakan Pemerintah Daerah DIY \\ Dalam Membangun Ketahanan Pangan \\ di Era Pandemi Covid-19
}

\section{Innovation Policy Of Yogyakarta Special Regional Government In Building Food Security In The Era Of Covid-19 Pandemic}

\section{OPEN ACCESS}

Citation: Kaulika, R., Wattimena, Z., Septiyanti, M., \& Mutiarin, D. (2021). Inovas Kebijakan Pemerintah Daerah DIY Dalam Membangun Ketahanan Pangan Di Era Pandemi Covid-19. Matra Pembaruan. 5(2), 127-139

Received: January 12, 2021

Accepted: February 26, 2021

Published: November 29, 2021

(c) The Author(s)

\section{(c) (i) (2) (2)}

This work is licensed under a Creative Commons Attribution-NonCommercialShareAlike 4.0 International License.

Kata Kunci: Daerah Istimewa Yogyakarta, inovasi kebijakan, ketahanan pangan, pandemi, pemerintah daerah.

Keywords: Daerah Istimewa Yogyakarta, Food Security, Local Government, Pandemic, Public Policy Innovation.

\author{
Zarita Kaulika R. Wattimena ${ }^{1}$, Murni Septiyanti ${ }^{2}$, Dyah Mutiarin $\left(\right.$ (D) $_{3^{*}}$ \\ 1,2 Mahasiswa Prodi Magister Ketahanan Nasional Universitas Gadjah Mada \\ Jl. Bulaksumur, Caturtunggal, Kec. Depok, Kabupaten Sleman, Daerah Istimewa Yogyakarta 55281 \\ ${ }^{3}$ Dosen Magister Ilmu Pemerintahan Universitas Muhammadiyah Yogyakarta \\ Jl. Brawijaya, Geblagan, Tamantirto, Kec. Kasihan, Bantul, Daerah Istimewa Yogyakarta 55183 \\ $\mathbf{m}$ mutiarin@umy.ac.id
}

Abstrak: Tujuan penelitian ini adalah untuk menganalisis inovasi kebijakan pemerintah daerah Provinsi Daerah Istimewa Yogyakarta dalam meningkatkan ketahanan pangan masyarakat di era pandemi saat ini. Provinsi DIY merupakan salah satu daerah yang terkena dampak besar dari penyebaran virus Corona. Walaupun tidak termasuk daerah dengan jumlah terkonfirmasi penderita Covid-19 yang tinggi, dampak besar dialami Provinsi DIY dikarenakan sebagian besar sumber pendapatan daerah dan masyarakatnya adalah dari industri pariwisata. Hal ini mempengaruhi ketahanan ekonomi dan ketahanan pangan masyarakat di mana perekonomian masyarakat menurun yang menyebabkan ketahanan pangan terganggu. Pergeseran paradigma administrasi publik ke arah agile government mengharuskan pemerintah untuk dengan cepat dan hati-hati menyusun inovasi kebijakan publik untuk menyelamatkan masyarakat dari dampak pandemi yang masih berlanjut. Peneliti menggunakan metode wawancara dan metode Analisis Data Sekunder, yaitu pendataan melalui penelitian dari berbagai jenis dokumen seperti berita, jurnal, buku, makalah dan sebagainya. Data berupa hasil wawancara dan berbagai jurnal, berita serta artikel terkait tersebut akan diolah dengan software Nvivo agar penyajian data lebih efektif dan efisien. Hasil penelitian ini menunjukkan bahwa sub sistem ketahanan pangan yang paling terdampak di Provinsi DIY adalah bidang konsumsi. Aktor penting terselenggaranya inovasi kebijakan ketahanan Provinsi DIY adalah pemerintah daerah melalui DPKP Provinsi DIY yang telah melakukan inovasi masing-masing di bidang produksi, konsumsi, dan distribusi bahan pangan.

\begin{abstract}
The purpose of this research is to analyze policy innovations of the local government of Yogyakarta Special Region Province in improving people's food security in the current pandemic era. DIY province is one of the areas affected by the spread of the Corona virus. Although this province does not include in areas with a high number of confirmed Covid-19 patients, the big impact experienced by DIY Province is because most of the sources of local and community income are from tourism industry. This affects the economic security and food security of the community where the community's economy is declining which causes food security to be disrupted. The paradigm shift of public administration towards agile government requires the government to quickly and carefully develop public policy innovations to save the public from the impact of the ongoing pandemic. Researchers used interview methods and Secondary Data Analysis methods, namely data collection through research from various types of documents such as news, journals, books, papers and so on. Data in the form of interviews and various journals, news and related articles will be processed with Nvivo software to make data presentation more effective and efficient. The results of this study indicate that the food security sub-system most affected in DIY Province is the consumption sector. The important actor in implementing the DIY Province's resilience policy innovation is the regional government through the DIY Provincial DPKP which has made their respective innovations in the fields of production, consumption and distribution of foodstuffs.
\end{abstract}




\section{Pendahuluan}

Penyelenggaraan birokrasi di Indonesia telah melewati berbagai fase perkembangan paradigma demi terciptanya lingkungan birokrasi yang dapat memberikan kepuasan masyarakat dan manfaat maksimal dalam penyelenggaraan kenegaraan. Perkembangan paradigma yang pernah dilaksanakan di Indonesia antara lain adalah New Public Management, New Public Service hingga Good Governance. Perkembangan paradigma tersebut menunjukkan upaya pemerintah untuk terus meningkatkan kualitas birokrasi baik dalam hal penyusunan dan implementasi kebijakan hingga manajemen pelayanan publik sesuai dengan tuntutan zaman. Dalam perkembangannya saat ini, birokrasi dituntut untuk bertransformasi menjadi agile government (pemerintahan cergas). Dalam membedakan konsep agile government dengan paradigma - paradigma sebelumnya adalah bahwa semangatnya bukan saja untuk menciptakan sistem manajemen publik yang lincah dan responsif dengan struktur organisasi yang adaptif, tetapi juga menyesuaikan diri dengan tantangan dan sekaligus peluang industri 4.0 (Purwanto, 2019a)

Untuk mewujudkan agile government pemerintah dituntut tidak hanya berfokus dalam melaksanakan pelayanan prima namun juga "luwes" dalam penentuan kebijakan sesuai dengan situasi, kondisi dan kebutuhan terkini dari lingkungan. Inovasi menjadi kunci penting terlaksananya suatu pemerintahan yang cergas. Kebijakan publik dirancang dengan inovatif guna menghasilkan ide-ide baru dalam bidang pengetahuan, namun perlu diperhatikan dalam kebijakan public yang diangkat perlu mendasari pada sebuah kebijakan dimana dapat mengaitkan dan menangani permasalahan sosial dan ekonomi yang muncul dikalangan masyarakat (Purwanto, 2019b). Saat memasuki era pandemi Covid-19 di tahun 2020 yang memberikan dampak luar biasa kepada seluruh lapisan masyarakat, pemerintah dituntut untuk menyesuaikan diri sesuai dengan prinsip-prinsip agile government melalui suatu inovasi kebijakan publik.

Sebagai salah satu upaya dalam penanggulangan pandemi Covid-19, pemerintah Indonesia telah memberlakukan berbagai langkah yang gunanya untuk melindungi kesehatan masyarakat termasuk dalam penerapan Pembatasan Sosial Berskala Besar yang telah diatur dalam Peraturan Menteri Kesehatan Nomor 9 Tahun 2020 tentang Pedoman Dalam Pembatasan Sosial Berskala Besar sebagai upaya percepatan penanganan Covid-19. Selain itu juga upaya yang dilakukan pemerintah lainnya adalah adanya pembatasan pada sektor Pendidikan dan bisnis, pembatasan perpindahan atau mobilisasi penduduk, dan pembatasan perjalanan internasional.

Beberapa daerah seperti Jakarta, Jawa Timur dan Jawa Barat yang merupakan provinsi dengan jumlah kasus terkonfirmasi Covid-19 tertinggi di Indonesia mengharuskan untuk menerapkan kebijakan Pembatasan Sosial Berskala Besar (PSBB) yang mengakibatkan berbagai bidang seperti pabrik, kantor pemerintahan, serta usaha dagang harus menghentikan usahanya yang berujung pada penurunan aktivitas perekonomian dan meningkatnya jumlah masyarakat yang mengalami Pemutusan Hubungan Kerja (PHK). Sedangkan daerah lain seperti Bali, Yogyakarta dan Nusa Tenggara Timur sangat berdampak pada bidang pariwisata karena provinsi tersebut mengandalkan pariwisata sebagai pendapatan terbesar bagi masyarakatnya. Apabila pemerintah tidak mengambil langkah-langkah kebijakan dengan cepat dan cermat tentunya dampak dari pandemi ini akan semakin meluas dan mengakibatkan menurunnya kesejahteraan dan ketenteraman bangsa.

Provinsi Daerah Istimewa Yogyakarta merupakan salah satu daerah yang terkena dampak besar dari penyebaran virus Corona ini. Beberapa dampak nyata pandemi yang dialami Provinsi DIY adalah kerugian di sektor pariwisata sebesar 67,04 miliar pada bulan April 2020, menurunnya pendapatan UMKM sebesar 80\%, hingga sejumlah 1.465 pekerja telah terkena PHK. Menurut data yang diperoleh dari website https://corona.jogjaprov.go.id/, pada tanggal 19 Oktober 2020 jumlah total penduduk terkonfirmasi positif Covid-19 di Provinsi DIY adalah sebanyak 3.343 orang. Walaupun tidak termasuk daerah dengan jumlah terkonfirmasi penderita Covid-19 yang tinggi, dampak besar dialami Provinsi DIY dikarenakan sebagian besar sumber pendapatan daerah dan masyarakatnya adalah dari industri pariwisata. Kebijakan PSBB serta 
larangan untuk melakukan perjalanan antar daerah baik di dalam maupun luar negeri tentunya telah mematikan industri pariwisata di DIY selama masa pandemi.

Ketahanan pangan merupakan hal penting yang perlu menjadi perhatian pemerintah di masa pandemi ini. Selain menjaga kondisi perekonomian tetap stabil, kesehatan masyarakat juga perlu diutamakan. Ketahanan pangan adalah salah satu faktor penentu ketahanan nasional suatu bangsa. Sektor konsumsi pangan memiliki peran yang sangat vital dan strategis pada setiap negara. Di masa pandemi, ketahanan pangan juga menjadi isu sentral bagi pembangunan nasional yang mengaitkan pembangunan di sektor pertanian dan sektor perekonomian. Dimana isu ketahanan pangan ini didasari pada focus kebijaksanaan operasional pembangunan pertanian dalam Kabinet Persatuan Nasional (1999-2004) di samping focus lainnya yaitu pengembangan pada sektor agribisnis (Syahyuti et al., 2017).

Ketahanan pangan menjadi isu strategi pemerintah dalam meningkatkan pembangunan masyarakat (Simatupang, 2016). Sebagai upaya mewujudkan ketahanan pangan bagi masyarakat, dalam hal ini kaitannya terhadap sektor pertanian akan menjadi komoditi utama bagi masyarkat dalam penyedia pangan (Yetrie Ludang, 2021). Seperti yang telah diterapkan di beberapa negara besar, dimana suatu negara memiliki perkembangan yang begitu pesat dalam penyediaan pasokan pangan dimana hal ini menjadi sasaran utama dalam pembangunan ekonomi suatu negara. Hal ini juga diterapkan oleh pemerintah indonesia dibawah naungan Menteri sosial dan perekonomian dimana pasokan pangan menjadi hal yang urgensi bagi masyarakat, dimana nantinya pemerintah wajib menyediakan kebutuhan komoditi utama masyarakat(Sofianto, 2020)

Suharyanto (2011) menyebutkan bahwa pemerintah Indonesia memiliki sistem ketahanan pangan diantaranya adalah:

a. Adanya ketersediaan pangan dalam jumlah dan jenis yang cukup untuk seluruh penduduk.

b. Adanya pemerataan pada distribusi pangan

c. Konsumsi pangan setiap individu yang memenuhi kecakupan gizi

d. Prioritas status gizi masyarakat dimana ini akan menjadi otoritas dari masingmasing daerah.

Khususnya mengenai pandemi Covid-19 dimana antar daerah terkena dampak dalam bentuk dan skala yang berbeda. Disinilah letak peran penting pemerintah daerah dalam mewujudkan agile government sebagai jawaban dari kebutuhan daerah masing - masing untuk menyesuaikan diri atau malah mengubah tantangan dampak pandemi menjadi sebuah peluang bagi kemajuan daerahnya. Sururi (2017) menyebutkan bahwa di tingkat pemerintahan baik pemerintah di level lokal maupun pusat, kemampuan dalam merumuskan kebijakan public menjadi hal yang esensial dan memiliki urgensi dalam proses pelaksanaannya, dimana proses pembuatan kebijakan ini harus didasari dengan nilai-nilai kreativitas dan inovasi untuk meningkatkan efektifitas dan efisiensi dari penerapan kebijakan tersebut. Melalui penjelasan tersebut, keberhasilan inovasi kebijakan sangat erat dengan potensi serta kreativitas birokrasi masing-masing daerah.

Setiap daerah memiliki otoritasnya masing-masing dalam pengambilan suatu kebijakan, khususnya mengenai pandemi Covid-19 dimana antar daerah terkena dampak dalam bentuk dan skala yang berbeda. Disinilah letak peran penting pemerintah daerah dalam mewujudkan agile government sebagai jawaban dari kebutuhan daerah masing-masing untuk menyesuaikan diri atau malah mengubah tantangan dampak pandemi menjadi sebuah peluang bagi kemajuan daerahnya.

Rosyadi \& indiahono (2017) mengutarakan bahwa dalam menerapkan inovasi pada kebijakan pemerintah perlu diterapkannya input yang baru dan dalam menjalankan input yang diharapkan harus beriringan dengan output dan outcome yang relevan. Kebaruan menjadi fokus utama dalam definisi tersebut, sehingga untuk melakukan inovasi dibutuhkan cara pandang yang baru untuk melihat hal-hal apa sajakah yang belum ada atau belum pernah dijalankan sebelumnya. Inovasi dapat dikatakan sebagai sesuatu yang lebih dari sekedar hal-hal tangible namun juga hal -hal intangible yang diharapkan akan membawa dampak luas bagi organisasi secara khusus atau 
masyarakat secara umum. Wicaksono (2019) lebih lanjut mengungkapkan bahwa inovasi perlu dipahami sebagai rangkaian perubahan dalam sebuah sistem yang kompleks, tidak hanya menyangkut hal-hal yang sifatnya terlihat secara fisik yang digunakan di dalam organisasi tetapi juga lingkungan pasar, pengetahuan dan fasilitas produksi dan konteks sosial dari inovasi suatu institusi. Inovasi dapat dikatakan sebagai sesuatu yang lebih dari sekedar hal-hal tangible namun juga hal -hal intangible yang diharapkan akan membawa dampak luas bagi organisasi secara khusus atau bagian masyarakat secara umum.

Dalam penelitian lain banyak analisis telah dilakukan pada pengaruh pandemi dan respons kebijakan pembatasan sosial terhadap sektor pertanian, mulai dari produksi, pengolahan, transportasi dan distribusi maupun logistik pangan, sampai pada konsumsi (Cardwell \& Ghazalian, 2020; Gray, 2020; Petetin, 2020). Dalam setiap rekomendasi dari kajian maupun analisis tersebut disarankan pentingnya peran pemerintah dalam menjamin ketersediaan pangan, kelancaran distribusi, stabilitasi harga, serta menjaga daya beli petani (Cardwell \& Ghazalian, 2020; Petetin, 2020). Bank Dunia maupun FAO mengeluarkan peringatan pentingnya menjamin sektor pertanian tetap berjalan dengan aman untuk menjamin kecukupan pangan (VOS \& CATTANEO, 2021). Pemanfaatan teknologi termasuk artificial intelligence untuk mendorong transformasi sistem pangan dan pertanian dalam memenuhi kebutuhan pangan yang terus meningkat, serta menjaga kelestarian sumber daya pertanian di tengah tantangan perubahan iklim dan tekanan termasuk pandemi Covid-19.

Dari penjelasan tersebut terlihat bahwa ketahanan pangan tidak hanya mencakup pada kecukupan pangan seluruh penduduk namun juga memperhatikan aspek pendistribusian yang merata serta pemenuhan gizi masyarakat yang seimbang sehingga tidak terjadi ketimpangan pemenuhan pangan antar daerah baik secara kuantitas maupun kualitas.

Dalam penerapan ketahanan pangan di era otonomi daerah ini menjadi upaya yang harus dilakukan oleh masing-masing pemerintah daerah. Pelaksanaan otonomi daerah akan mengutamakan bagaimana potensi dan kebutuhan dari masing-masing daerah untuk mengurus urusan daerahnya sendiri. Dimana hal ini akan mempermudah peran pemerintah pusat dalam mengalokasikan kebutuhan setiap daerah yang memiliki perbedaaan dalam potensi dan kebutuhan sumber daya manusia lainnya. Pembangunan pada sektor pertanian khususnya pada peningkatan ketahanan pangan. Dimana pembangunan pertanian pada era otonomi daerah ini akan lebih mengandalkan kreativitas rakyat di setiap daerah.

Di era pandemi Covid-19, Pemerintah Provinsi DIY harus cepat tanggap dalam memberikan inovasi-inovasi kebijakan terkait dengan meningkatkan ketahanan pangan masyarakat, segala inovasi kebijakan pemerintah dalam menanggulangi virus corona harus dilakukan dengan perencanaan yang matang, karena apabila penanggulangannya tidak dilakukan secara matang, dikhawatirkan ketersediaan pangan dan perekonomian masyarakat DIY akan semakin mengerucut dan dampak negatifnya terhadap perekonomian dan kesejahteraan masyarakat provinsi DIY justru akan jauh lebih besar. Oleh karena itu, penulis akan berfokus kepada dampak pandemi Covid-19 terhadap ketahanan pangan pada Provinsi DIY serta peran para aktor pemangku kebijakan dalam menyusun inovasi kebijakan dalam rangka memperkuat ketahanan pangan di Provinsi DIY di era pandemi.

\section{Metode}

Penelitian ini akan menggunakan jenis penelitian deskriptif kualitatif. Dalam penelitian ini, digunakan 2 sumber data yaitu sumber data primer dan sumber data sekunder. Sumber data primer dikumpulkan melalui wawancara langsung kepada subjek penelitian, yaitu antara lain informan dari dinas terkait, yaitu Dinas Pertanian dan Ketahanan Pangan (DPKP) Provinsi Daerah Istimewa Yogyakarta. Sedangkan data sekunder dalam penelitian ini menggunakan data resmi milik pemerintah (DPKP, 2020).

Penelitian ini menggunakan teknik olah data dari aplikasi NVivo. Dimana, Aplikasi NVivo ini digunakan untuk mengetahui persentase dari masing-masing keterlibatan 
Tabel 1. Data Produksi Bahan Pangan DIY 2017 s.d. 2020 stakeholder dalam mencapai perumusan kebijakan, dan penanganan terhadap ketahanan pangan di provinsi daerah istimewa Yogyakarta. Aplikasi NVivo digunakan untuk mengolah data hasil wawancara yang telah dilakukan dengan Dinas Pertanian dan Ketahanan Pangan Daerah Istimewa Yogyakarta. Serta pengolahan data menggunakan data sekunder diperuntukan untuk memperkuat argumen yang muncul dalam hasil wawancara yang telah dilakukan dengan mewawancarai 2 pegawai Dinas Pertanian DIY dan 2 masyarakat yang fokus pada kajian ketahanan pangan. Data sekunder yang diolah pada penelitian ini berupa hasil persentase data ketahanan pangan di tahun 2017 sampai 2020, sehingga mengetahui pola ketahanan pangan seperti apa yang terjadi di Provinsi Daerah Istimewa Yogyakarta.

\section{Hasil Dan Pembahasan}

\section{III.1. Dampak Covid-19 terhadap Ketahanan Pangan}

Dalam penelitian ini, peneliti menggunakan 3 indikator sub sistem ketahanan pangan yang dikemukakan oleh Suharyanto (Suharyanto, 2011) yang meliputi ketersediaan jumlah dan jenis pangan (produksi) yang cukup, konsumsi pangan individu, dan distribusi yang lancar dan merata.

\section{Produksi}

Berdasarkan peraturan yang diatur dalam Undang-Undang Pangan No.7 Tahun 1996 menjelaskan bahwasannya kondisi ketahanan pangan harus dipenuhi dalam hal ini adalah kebutuhan pangan bagi rumah tangga yang tercermin dari tersedianya pangan secara merata dan cukup baik secara kualitas dan kuantiti. Di tengah menurunnya pendapatan berbagai sektor seperti pariwisata, industri jasa, ataupun perdagangan, hal tersebut merupakan bukti bahwa produksi bahan pangan DIY merupakan salah satu sektor yang dapat mengatasi hambatan dan tantangan dalam masa pandemi ini menjadi kekuatan bagi daerah. Tren produksi bahan pangan DIY pada tahun 2020 dapat dilihat dari tabel berikut:

\begin{tabular}{|c|c|c|c|c|c|c|}
\hline \multirow{2}{*}{ No } & \multirow{2}{*}{ Komoditi } & \multirow{2}{*}{ Satuan } & \multicolumn{4}{|c|}{ Produksi Tahun } \\
\hline & & & 2017 & 2018 & 2019 & 2020 \\
\hline 1 & Padi & (Ton) & 808.193 & 783.801 & 745.950 & 834.350 \\
\hline 2 & Beras & (Ton) & 507.060 & 491.757 & 470.396 & 526.141 \\
\hline 3 & Jagung & (Ton) & 311.764 & 309.221 & 366.031 & 361.240 \\
\hline 4 & Bawang Merah & (Ton) & 9.025 & 9.652 & 10.974 & 17.068 \\
\hline 5 & Cabe Merah & (Ton) & 37.903 & 44.590 & 42.972 & 30.630 \\
\hline 6 & Telur & (Ton) & 26.355 & 27.094 & 27.296 & 27.936 \\
\hline 7 & Daging Ayam & (Ton) & 22.909 & 20.339 & 19.965 & 21.690 \\
\hline 8 & Daging Sapi & (Ton) & 5.775 & 6.655 & 5.623 & 3.508 \\
\hline 9 & Gula Pasir & (Ton) & 44.584 & 70.200 & 24.049 & 18.478 \\
\hline
\end{tabular}

Sumber: Dinas Pertanian dan Ketahanan Pangan Provinsi DIY, 2020

Di masa pandemi ini, hasil pada tabel 1 menunjukan bahwa tidak ada hasil yang cukup signifikan menurun yang disebabkan oleh wabah Covid-19. Akan tetapi hasil tersebut akan memberikan gambaran atas perilaku masyarakat di daerah istimewa Yogyakarta akan nilai produksi bahan pangan yang dibutuhkan, misalnya hasil produksi bahan pangan yang mengalami kemerosotan yakni Jagung, Cabe Merah, Daging Sapi, dan Gula Pasir.

\section{Konsumsi}

Dinas Pertanian dan Ketahanan Provinsi DIY telah melakukan pemantauan kondisi stok pangan dan pola konsumsi masyarakat saat terjadi pandemi Covid-19 menyebutkan bahwa terjadi penurunan tingkat konsumsi di masyarakat. Sedangkan 
untuk pola konsumsi, Dinas Pertanian dan Pangan Kota Yogyakarta membedakannya dalam dua kategori yaitu pola konsumsi rumah tangga dan pola konsumsi industri pendukung jasa pariwisata. Untuk konsumsi rumah tangga, tidak terjadi penurunan tingkat konsumsi yang signifikan selama pandemi Covid-19 yaitu turun 5\% hingga 10\%. Tren produksi beras di DIY pada tahun 2020 memang menurun (lihat tabel 2.1), tetapi jumlah ketersediaan beras tetap mencukupi kebutuhan karena diimbangi dengan menurunnya kebutuhan bahan pangan masyarakat dengan berkurangnya jumlah penduduk yang menetap di DIY selama masa pandemi. Dari data tersebut, dapat dilihat bahwa pandemi Covid-19 berdampak pada menurunnya konsumsi bahan pangan di Provinsi DIY. Selain disebabkan karena menurunnya penghasilan masyarakat selama masa pandemi, hal tersebut juga terjadi karena menurunnya jumlah penduduk di Provinsi DIY.

\section{Distribusi}

Dalam hal distribusi pangan, permasalahan utama yang marak terjadi adalah tingginya angka disparitas harga antara produsen dan konsumen yang dimana akan mengakibatkan keuntungan yang tidak proporsional antara pelaku usaha dan konsumen. Harga yang tinggi di tingkat konsumen tidak menjamin produsen dalam hal ini sektor pertanian mendapatkan harga yang layak, sehingga hal ini perlu diperhatikan oleh pemerintah untuk menjaga keseimbangan harga yang dapat memberikan mutual beneficiary.

Menurut DPKP Provinsi DIY, selama masa pandemi, meskipun sebagian bahan kebutuhan pokok di Kota Yogyakarta didatangkan dari luar daerah, tidak ada hambatan dalam proses distribusi sehingga ketersediaannya pun cukup untuk memenuhi kebutuhan masyarakat. Maka, dapat disimpulkan meski dikhawatirkan akan terjadi gangguan dalam pendistribusian bahan pangan baik di bidang pertanian maupun UMKM, namun kenyataanya distribusi bahan pangan di Provinsi DIY tidak mengalami hambatan berarti selama masa pandemi Covid-19.

\section{III.2. Strategi Untuk Meningkatkan Ketahanan Pangan}

Provinsi DIY telah mengeluarkan inovasi-inovasi kebijakan dalam membangun ketahanan pangan masyarakat di era pandemi saat ini. Inovasi-inovasi tersebut dapat dijabarkan dalam beberapa bagian yakni inovasi dalam bidang produksi, bidang konsumsi dan bidang distribusi.

\section{III.2.1. Inovasi dalam Bidang Produksi}

Sebagai lembaga yang bertugas dalam menjaga ketahanan pangan di Provinsi DIY, Dinas Pertanian dan Ketahanan Pangan (DPKP) Provinsi DIY pada bulan Juli 2020 telah memastikan bahwa ketersediaan bahan pangan di masyarakat telah tercukupi dengan baik. Dinas tersebut melakukan pendataan terhadap persediaan 11 jenis bahan kebutuhan pokok, seperti beras, gula pasir, minyak dan telur baik yang dijual di toko, pasar maupun di distributor. Rata-rata, semua komoditas dalam kondisi mencukupi. Pendataan tersebut dilakukan secara kontinyu untuk memastikan bahwa produk bahan pangan selalu tercukupi bagi kebutuhan masyarakat.

Provinsi DIY di masa pandemi ini telah memiliki cadangan pangan berupa beras yang disuplai atau disediakan oleh Perusahaan Umum Badan Urusan Logistik (Perum Bulog). Bulog sendiri menyediakan 100 ton beras per kabupaten / kota apabila terjadi bencana ataupun pada saat diperlukan. Sedangkan apabila provinsi yang membutuhkan, maka Bulog dapat menyediakan maksimal 200 ton. Di masa pandemi sampai bulan Desember 2020, cadangan beras dari Bulog tersebut belum pernah dikeluarkan. Hal tersebut memperlihatkan bahwa jumlah produksi beras saat ini di Provinsi DIY masih mencukupi.

Pada bulan Desember 2020, Dinas Pertanian dan Ketahanan Pangan DIY bahkan telah menambah cadangan beras sebesar 50 ton. Beras tersebut dititipkan kepada PT Taru Martani agar dapat dikelola sesuai dengan mekanisme yang telah disepakati dalam perjanjian Kerja Sama. Penyerahan beras yang pengadaanya melalui proses lelang tersebut berlangsung di gudang beras dan penggilingan salah satu mitra PT Taru Martani di Kecamatan Pengasih, Kulon Progo. Dengan penyerahan tersebut maka 
total Cadangan Pangan Pemerintah Daerah (CPPD) DIY yang dikelola oleh PT Taru Martani sejak tahun 2019 adalah sebesar 243,167 ton(News, 2020).

Selain dikelola oleh PT Taru Martani, CPPD DIY juga dikerjasamakan dengan BULOG di Gudang Purwomartani Kalasan sebesar 31,875 ton. Dengan demikian total CPPD yang dimiliki oleh Pemda DIY adalah sebesar 275,042 ton. Beras cadangan pangan tersebut dapat dikeluarkan sewaktu-waktu bilamana terjadi kekurangan Pangan, gejolak harga Pangan, bencana alam/sosial, dan/atau keadaan darurat sesuai dengan mekanisme yang telah diatur dalam Pergub DIY Nomor 115 tahun 2018 tentang Pedoman Penyelenggaraan Cadangan Pangan Pemerintah Daerah(Kedaulatan Rakyat, 2020a).

Selain menjaga dan menambah cadangan pangan di Provinsi DIY, berbagai inovasi telah dilaksanakan Pemda DIY dalam rangka menjaga agar proses produksi bahan pangan tetap berlangsung dan mencukupi kebutuhan daerah. Inovasi tersebut antara lain adalah:

\section{Lumbung Mataraman}

Di era pandemi saat ini, Lumbung Mataraman merupakan salah satu strategi pemerintah DIY dalam meningkatkan ketahanan pangan masyarakat di daerah, Lumbung Mataraman bukanlah bangunan fisik tetapi lumbung pangan hidup yang berbasis dari rumah tangga dan dalam pengembangannya diharapkan menjadi lumbung pangan desa yang dapat mendukung ketahanan pangan, kemandirian pangan, dan kedaulatan pangan di wilayah.

Melalui Kelompok Tani, Pemanfaatan lahan pekarangan rumah terus digalakkan oleh pemerintah Kota Yogyakarta. Kini Dinas Pertanian dan Pangan Kota Yogyakarta mencoba mengembangkan 'Lumbung Mataraman' pada Tahun Anggaran 2020 yang diperoleh dari Dana Keistimewaan. Terdapat tiga wilayah yang mendapatkan dana keistimewaan tahun anggaran 2020 yaitu di wilayah utara (Kebun Markisa di Kelurahan Karangwaru, Kecamatan Tegalrejo), barat (Kebun Pugeran di Kelurahan Suryodiningratan, Kecamatan Mantrijeron) dan timur (Balai RW 14 Kelurahan Purbayan, Kecamatan Kotagede).

Lumbung Mataraman yang dilaksanakan melalui anggaran Dana Keistimewaan untuk menghidupkan kembali tradisi pertanian di Yogyakarta yaitu memanfaatkan lahan pekarangan rumah tangga untuk menyediakan kebutuhan pangan dengan prinsip: kemandirian pangan, diversifikasi pangan berbasis sumber pangan lokal, pelestarian sumber daya genetik pangan, dan kebun bibit. Sehingga Melalui Lumbung Mataraman ini masyarakat, khususnya kelompok dapat merasakan manfaat adanya bantuan hibah dari Pemerintah Daerah DIY, dalam memenuhi kebutuhan pangan dan gizi keluarga, hemat pengeluaran belanja dan juga adanya peningkatan pendapatan rumah tangga disaat perekonomian negara sedang menurun akibat dari pandemik Covid-19 ini (COVID-19, 2020; DIY, 2018).

\section{Rumah Pangan Lestari}

Dalam hal ini pemerintah juga membentuk Kawasan Rumah Pangan Lestari yang digunakan untuk mewujudkan kerukunan tetangga yang dimana berfokuskan pada sumber pangan bagi masyarakat secara intensifikasi dan juga fasilitas lainnya, seperti adanya pemanfaatan pagar hidup, jalan desa, dan fasilitas umum lainnya seperti penyediaan sekolah, rumah ibadah, ruang terbuka hijau, serta pengembangan sektor ekonomi. Menurut Pelaksana Tugas (Plt) Kepala Dinas Pertanian dan Pangan Kota Yogyakarta Sugeng Darmanto, hingga saat ini sudah ada sekitar 40 kampung sayur yang tersebar di berbagai kecamatan(Kedaulatan Rakyat, 2020b; News, 2020).

Bentuk perwujudan yang dilakukan oleh pemerintah melalui rumah pangan lestari ini menjadi sebuah kemandirian bagi masyarakat dalam satu wilayah untuk mengupayakan sumber pangan. Untuk itu Rumah Pangan Lestari merupakan salah satu strategi pemerintah DIY dalam meningkatkan ketahanan pangan di bidang produksi apalagi di era pandemi saat ini, untuk itu perlunya komitmen dan konsistensi yang tumbuh di setiap individu. Sehingga ketika terjadi pergantian musim atau cuaca ekstrem, jenis tanaman sayur yang ditanam bisa disesuaikan agar tetap dapat dipanen dan masyarakat mampu bertahan jika terjadinya krisis pangan di era pandemi saat ini. Jika dilihat secara makro ketersediaan pangan telah melebihi kapasitas cakupan 
energi dan protein di tingkat nasional.

Di era pandemi ini, ketahanan pangan menjadi permasalahan utama dan munculnya fakta bahwa pertumbuhan permintaan pangan yang lebih cepat dari tahun sebelumnya. Permintaan yang meningkat ini merupakan dampak yang muncul dari peningkatan jumlah penduduk, pertumbuhan ekonomi, dan adanya peningkatan daya beli masyarakat dan perubahan atas kebutuhan yang dibutuhkan. Tetapi hal yang terjadi adalah, kapasitas produksi pangan nasional dalam pertumbuhan pangannya memiliki kelambatan bahkan stagnan yang disebabkan oleh adanya kompetisi dalam pemanfaatan sumberdaya lahan dan air serta tidak adanya perubahan yang signifikan dalam pemanfaatan sumberdaya lahan dan air serta adanya pertumbuhan produktivitas lahan serta tenaga kerja pertanian.

Beberapa upaya yang dapat dilakukan oleh pemerintah dalam upaya percepatan diversifikasi pangan yaitu:

a) Dilaksanakannya sosialisasi dan internalisasi, promosi dan promosi rencana aksi diversifikasi pangan.

b) Tersedianya peningkatan pangan berbasis pada potensi sumberdaya wilayah yang berwawasan lingkungan.

c) Peningkatan kemampuan dan kapasitas sumberdaya manusia dalam pengembangan diversifikasi produktivitas.

d) Pemberdayaan masyarakat dalam pengembangan diversifikasi pangan.

e) Penyediaan dan pengembangan akses pangan dalam pemantapan ketahanan pangan keluarga.

f) Pengembangan tingkat kewaspadaan pangan dan gizi.

g) Melakukan monitoring kegiatan diversifikasi pangan dalam hal ketahanan pangan.

Tantangan yang muncul dalam ketahanan pangan nasional yaitu:

a) Adanya keberlanjutan konversi lahan pertanian untuk kegiatan non pertanian.

b) Dalam hal teknologi produksi menggunakan benih unggul dan pupuk kimia yang secara intensif diterapkan sejak awal 70-an.

c) Adanya kebijakan pengembangan komoditas pangan, termasuk adanya teknologi dalam potensi sumber pangan karbohidrat.

d) Adanya penggunaan teknologi pada hasil pasca panen sehingga memudarnya hasil dan degradasi mutu dari pangan tersebut.

e) Prasarana dan mobilitas yang belum memadai.

Tentunya jika dilihat secara luas, tantangan yang muncul disebabkan dengan adanya pengembangan teknologi di sektor pertanian, dimana akan meningkatkan efisiensi yang mencakup spektrum teknologi yang sangat luas dari sektor teknologi yang terkait dengan teknologi pengembangan sarana produksi bahan pangan.

Bentuk diversifikasi yang direkomendasikan untuk mendukung produksi ketahanan pangan ini dapat dilihat secara horizontal dan regional. Bentuk diversifikasi horizontal akan mengembangkan usaha tani dalam hal komoditi unggulan serta mengembangkan usaha tani pada komoditas lainnya seperti adanya optimalisasi pemanfaatan sumber daya alam, dan sektor mikro dalam jenis usaha. Sedangkan diversifikasi regional ini guna mengembangkan komoditas pertanian unggulan yang lebih spesifik dilihat dari sektor lokasi dan kawasan yang sesuai dengan kondisi agroekosistem yang muncul, dengan demikian akan mendorong pengembangan sentra-sentra produksi pertanian di berbagai wilayah tertentu untuk mendorong pengembangan sektor perdagangan antar wilayah.

Kebutuhan akan pangan akan berbeda dengan produk pangan pada umumnya, dimana produk pangan ini akan mengikuti produksi musiman, sedangkan kebutuhan pangan perlu dipenuhi sepanjang tahun. dimana jika di aplikasikan di indonesia, maka produksi pangan tersebar berdasarkan kondisi agroekosistem dan geografinya, sedangkan lokasi konsumen tersebar di seluruh pelosok tanah air, baik di wilayah perkotaan maupun pedesaan. Oleh sebab itu, tingkat mobilitas dalam pendistribusian pangan menjadi sangat vital dalam rangka penyediaan pangan yang merata bagi penduduk Indonesia. 


\section{III.2.2. Inovasi dalam Bidang Konsumsi}

Di era pandemi saat ini, berbagai upaya dan strategi telah dilakukan oleh pemerintah Yogyakarta guna menjaga ketahanan pangan dalam rangka memenuhi kebutuhan konsumsi masyarakat DIY. Seperti data tren produksi bahan pangan DIY pada tahun 2020 yang disajikan pada tabel 2.1 menunjukkan bahwa produksi bahan pangan di era pandemi saat ini tidak mengalami perubahan yang cukup signifikan. Namun menurut Dinas Pertanian dan Ketahanan Provinsi DIY yang telah melakukan pemantauan kondisi stok pangan dan pola konsumsi masyarakat saat terjadi pandemi menyebutkan bahwa terjadi penurunan tingkat konsumsi bahan pangan di masyarakat.

Untuk mengatasi dan menjaga kestabilan ketahanan pangan masyarakat DIY di era pandemi saat ini, pemerintah kemudian mengeluarkan salah satu kebijakan yang untuk mendorong tingkat konsumsi masyarakat selama masa pandemi yakni melalui pemberian Bantuan Langsung Tunai (BLT) kepada warga miskin yang terdampak pandemi. Pemberian bantuan tersebut terbukti mampu menjaga konsumsi masyarakat lokal sehingga penurunan tingkat konsumsi sangat kecil dan dapat diatasi.

\section{III.2.3. Inovasi dalam Bidang Distribusi}

Pemerintah DIY terus berupaya memenuhi kebutuhan pangan terutama pangan pokok melalui berbagai macam program. Agar pangan yang disediakan mampu dikonsumsi oleh masyarakat maka diperlukan akses atau distribusi pangan yang efisien. Akses pangan yang baik apabila semua masyarakat mempunyai sumber daya yang cukup untuk mendapatkan pangan yang cukup secara kuantitatif dan kualitatif.

Bidang Ketersediaan dan Distribusi Pangan Badan Ketahanan Pangan dan Penyuluhan DIY menyelenggarakan kegiatan Sosialisasi Akses Pangan untuk mempermudah Gapoktan (Gabungan Kelompok Tani Subur Makmur) mendapatkan bahan pangan. Dalam kegiatan ini BKPP DIY bersama Perum Bulog menyampaikan program Rumah Pangan Kita (RPK). Kegiatan ini dihadiri oleh 61 Gapoktan se-DIY.

Selain sosialisasi, inovasi lain yang dilakukan oleh Badan Ketahanan Pangan dan Penyuluhan DIY adalah membuat forum yang bertujuan membentuk kerjasama antara Gapoktan dan Kopassindo. Manfaat dari diadakannya kerjasama ini yaitu dapat memangkas rantai distribusi produk pertanian, memudahkan Gapoktan dalam pemasaran, menjaga ketersediaan pasokan dan stabilitas harga.

Sebagai solusi permanen dalam mengatasi disparitas harga pangan, Pemerintah cq. Kementerian Pertanian (Kementan) melakukan terobosan melalui kegiatan Pengembangan Usaha Pangan Masyarakat (PUPM) melalui Toko Tani Indonesia Center (TTIC). Kegiatan ini dilakukan sebagai upaya untuk menjaga stabilitas pasokan dan harga pangan pokok strategis dan efisiensi rantai distribusi pemasaran dengan memperpendek rantai pasok.

Sebagai tindak lanjut program PUPM Kementan, DPKP Provinsi DIY saat ini telah memulai pendistribusian bahan pangan melalui pemasaran secara daring, salah satunya adalah melalui Toko Tani Indonesia. Toko Tani Indonesia telah menyediakan bahan-bahan pokok kebutuhan rumah tangga seperti beras, gula, ubi, dan sebagainya. Toko Tani hingga saat ini telah membantu pendistribusian bahan pangan di DIY dengan memberikan subsidi gratis ongkos kirim hingga Rp 40.000,00. Subsidi tersebut telah dimanfaatkan dengan baik oleh masyarakat.

DPKP Provinsi DIY juga bekerjasama dengan platform digital yang menyediakan jasa ojek online yaitu Gojek untuk menghadirkan layanan Toko Tani Indonesia Center (TTIC) Yogyakarta di layanan Go Shop. Melalui aplikasi berbasis digital tersebut, barang belanjaan berupa bahan pangan bisa langsung diantar ke rumah masingmasing pemesan. Adanya kerja sama dengan Gojek dan penyedia jasa distribusi lainnya semakin memudahkan masyarakat mendapat bahan pangan di tengah imbauan pemerintah untuk tetap di rumah. Terdapat dua manfaat dengan kerja sama ini seperti yang diungkapkan oleh Kepala Badan Ketahanan Pangan Kementan, yaitu di satu sisi, mitra driver ojek online mendapat penghasilan karena mendapat tambahan pelanggan, di sisi lain masyarakat mendapat kemudahan untuk memperoleh bahan pangan tanpa keluar rumah karena ada imbauan di rumah saja. 
Gambar 1. Peran Kementerian Pertanian dalam Ketahanan Pangan Provinsi DIY

Gambar 2. Peran DPKP Provinsi DIY dalam Ketahanan Pangan Provinsi DIY

\section{III.3. Aktor dalam Inovasi Kebijakan Ketahanan Pangan Provinsi DIY}

Peran aktor dalam inovasi kebijakan menjadi kunci penting terselenggaranya inovasi yang berdampak pada masyarakat DIY. Peran berbagai aktor dalam inovasi kebijakan di bidang ketahanan pangan DIY terbagi ke dalam 3 aktor utama, yaitu pemerintah pusat yaitu Kementerian Pertanian, pemerintah daerah yaitu DPKP Provinsi DIY, dan masyarakat DIY sendiri. Peran masing-masing aktor dapat dilihat sebagai berikut:

\section{III.3.1. Kementerian Pertanian}

Melalui analisis data sekunder berupa artikel online pada Aplikasi Nvivo, dapat dilihat hubungan antara Kementerian Pertanian dalam inovasi kebijakan ketahanan pangan di Provinsi DIY sebagai berikut:

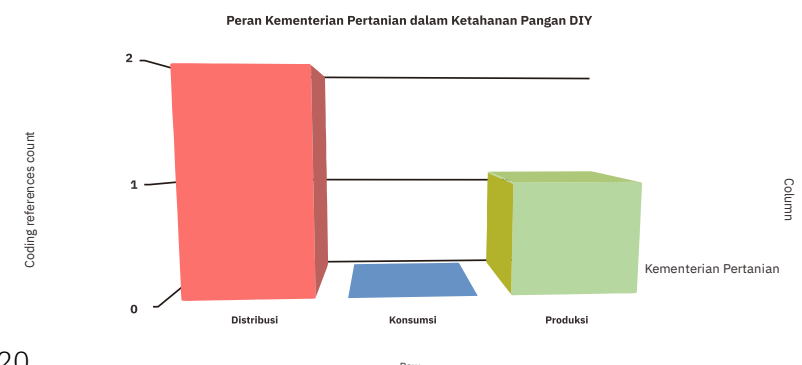

Sumber: Nvivo, 2020

Dari diagram di atas, terlihat bahwa Kementerian Pertanian berperan dominan dalam mengatur kebijakan dalam ketahanan pangan di Provinsi DIY khususnya pada proses produksi dan distribusi bahan pangan selama masa pandemi. Peran Kementerian Pertanian dalam proses distribusi selama masa pandemi terlihat pada inovasi kebijakan dimana diadakan kerja sama dengan platform digital ojek online dalam pendistribusian bahan pangan. Proses distribusi tersebut didukung dengan diberikannya subsidi ongkos kirim untuk meringankan masyarakat.

\section{III.3.2. Dinas Pertanian dan Ketahanan Pangan Provinsi DIY}

Melalui analisis data sekunder berupa artikel online pada aplikasi Nvivo, dapat dilihat hubungan antara DPKP Provinsi DIY dalam inovasi kebijakan ketahanan pangan di Provinsi DIY sebagai berikut :

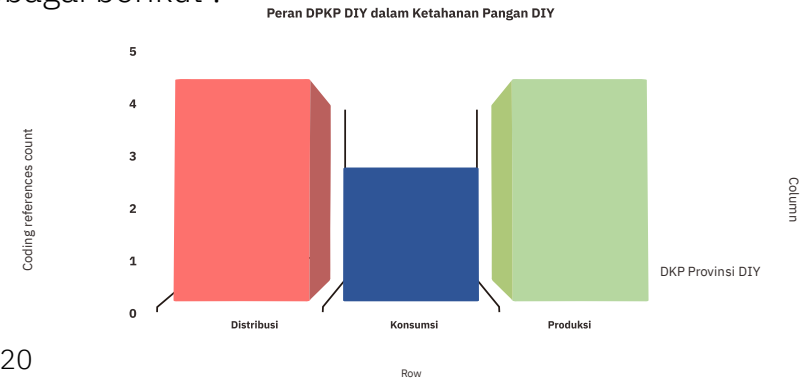

Sumber: Nvivo, 2020

Dari diagram di atas, terlihat bahwa DPKP Provinsi DIY memiliki peran dalam inovasi kebijakan ketahanan pangan baik di bidang produksi, konsumsi dan distribusi bahan pangan Provinsi DIY. Pada bidang produksi, DPKP DIY berperan dalam menyiapkan CPPD agar kebutuhan bahan pangan masyarakat tercukupi dalam masa pandemi. Selain itu, DPKP Provinsi DIY juga membuat suatu inovasi kebijakan berupa Lumbung Mataraman dan Rumah Pangan Lestari untuk menambah stok bahan pangan dengan memberdayakan lahan terbatas di sekitar lingkungan rumah masyarakat.

Di bidang konsumsi, DPKP DIY telah menyalurkan BLT kepada masyarakat untuk meningkatkan daya beli masyarakat akan bahan pangan sehingga gizi masyarakat tetap terpenuhi selama masa pandemi. DPKP DIY juga menggalakkan diversifikasi pangan agar keterbatasan jumlah bahan pangan khususnya beras dapat digantikan dengan berbagai jenis bahan pangan lain seperti umbi, kentang, jagung, dan sebagainya. Melalui diversifikasi pangan, konsumsi bahan pangan akan semakin merata dan gizi masyarakat akan tetap tercukupi walaupun tidak mengonsumsi beras. 
Gambar 3. Peran Masyarakat Provinsi DIY dalam Ketahanan Pangan Provinsi DIY

Gambar 4. Aktor dalam Inovasi Kebijakan Ketahanan Pangan Provinsi DIY di masa pandemi

\section{III.3.3. Masyarakat Provinsi DIY}

Melalui analisis data sekunder berupa artikel online pada aplikasi Nvivo, dapat dilihat hubungan antara Masyarakat Provinsi DIY dalam inovasi kebijakan ketahanan pangan di Provinsi DIY sebagai berikut:

Sumber: Nvivo, 2020

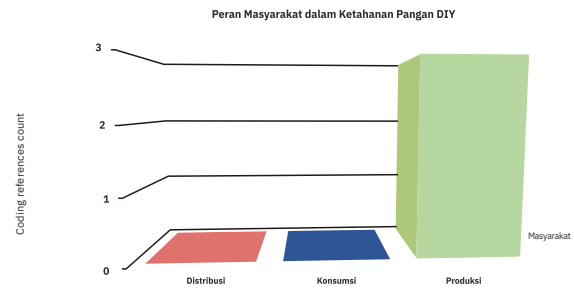

Dari diagram di atas, terlihat bahwa masyarakat Provinsi DIY memiliki peran dalam inovasi kebijakan ketahanan pangan di bidang produksi bahan pangan Provinsi DIY. Kebijakan Pemerintah Provinsi DIY yang langsung bersentuhan dengan masyarakat adalah melalui program Rumah Pangan Lestari (RPL). Terkait pemulihan ekonomi akibat Covid-19, konsep ketahanan pangan difokuskan sejak tingkat keluarga. Pemerintah mendorong ibu-ibu kelompok wanita tani memanfaatkan pekarangan rumah untuk ditanami sayuran konsumsi, antara lain berupa sayur seperti tomat, kangkung, terung, dan cabai. Seiring berjalannya waktu, program P2L dikembangkan di kebun. Komoditasnya pun tak hanya sayuran. Ada juga ikan dan ayam petelur. Hal ini bertujuan memenuhi kebutuhan gizi masyarakat secara mandiri.

Setelah melihat peran ketiga aktor tersebut dalam inovasi kebijakan ketahanan pangan di masa pandemi, khususnya di Provinsi DIY, dapat kita lihat bahwa masingmasing aktor memiliki peran yang berbeda. Melalui analisis data sekunder di aplikasi Nvivo, dapat kita lihat sebagai berikut :

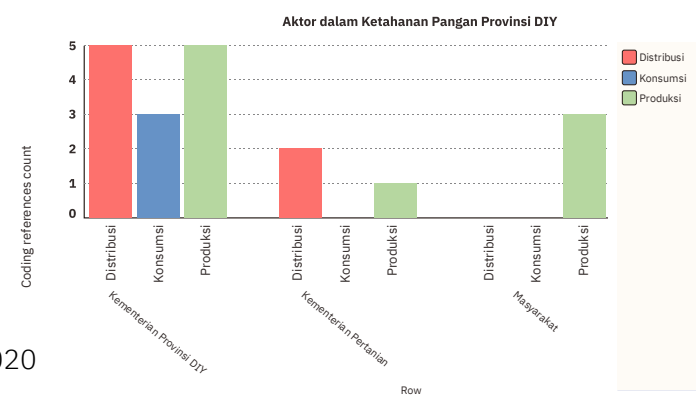

Sumber: Nvivo, 2020

Melalui diagram tersebut, aktor yang memiliki peran paling dominan adalah DPKP Provinsi DIY. DPKP Provinsi DIY yang merupakan lembaga yang bersinggungan langsung dengan ketahanan pangan masyarakat Provinsi DIY tentunya paling memahami bagaimana dampak yang dialami oleh masyarakat serta dapat menentukan langkah yang tepat untuk menanggulangi permasalahan ketahanan pangan yang terjadi di era pandemi saat ini. DPKP DIY telah menunjukkan peran aktifnya dalam membuat berbagai inovasi baik di bidang produksi, konsumsi dan distribusi sehingga ketahanan pangan di Provinsi DIY menunjukkan kontribusi positif dalam sektor perekonomian daerah sementara berbagai sektor lain seperti pariwisata, pendidikan dan perdagangan mengalami penurunan.

\section{Kesimpulan}

Dampak pandemi yang dialami Provinsi DIY yang di bidang produksi bahan pangan adalah penurunan produksi yang hanya dialami oleh beberapa komoditas saja seperti jagung, cabai merah dan daging sapi. Dampak pada bidang konsumsi adalah menurunnya konsumsi bahan pangan sebesar 5\% hingga 10\% yang diakibatkan menurunnya sektor pariwisata serta menurunnya jumlah penduduk pendatang di DIY yang pulang ke daerah asal masing-masing selama masa pandemi. Sedangkan bidang distribusi bahan pangan DIY tidak terlalu terdampak pandemi. Secara umum, sub sistem ketahanan pangan yang paling terdampak pandemi adalah konsumsi bahan pangan. 
Pemerintah DIY telah mengeluarkan inovasi-inovasi kebijakan dalam membangun ketahanan pangan masyarakat. Berbagai upaya dan strategi telah dilakukan oleh pemerintah Yogyakarta guna menjaga ketahanan pangan dalam rangka memenuhi kebutuhan pangan masyarakat DIY diantaranya ialah inovasi kebijakan dalam bidang produksi, bidang konsumsi dan di bidang distribusi. Di bidang produksi, telah disiapkan cadangan beras melalui Bulog, juga melaksanakan program Lumbung Mataraman dan Rumah Pangan Lestari. Di bidang konsumsi, Pemerintah DIY telah memberikan subsidi berupa BLT kepada masyarakat terdampak pandemi untuk meningkatkan daya beli serta mencanangkan diversifikasi pangan. Sedangkan di bidang distribusi, Pemerintah DIY menggagas Toko Tani Indonesia untuk mengatasi disparitas harga bahan pangan serta menggandeng startup ojek online untuk mendistribusikan bahan pangan dan memberikan subsidi ongkos kirim bagi masyarakat.

Pelaksanaan inovasi kebijakan ketahanan pangan di Provinsi DIY selama masa pandemi dijalankan oleh 3 aktor utama, yaitu Kementerian Pertanian, DPKP Provinsi DIY dan masyarakat DIY sendiri. Peran yang paling mendominasi dijalankan oleh DPKP DIY dimana lembaga tersebut menunjukkan peran aktifnya masing-masing dalam bidang produksi, konsumsi dan distribusi. Peran pemerintah daerah melalui DPKP DIY sangat terlihat dalam inovasi kebijakan ketahanan pangan Provinsi DIY selama masa pandemi.

\section{Daftar Referensi}

Cardwell, R., \& Ghazalian, P. L. (2020). COVID-19 and International Food Assistance: Policy proposals to keep food flowing. World Development, 135, 105059. https://doi.org/10.1016/j.worlddev.2020.105059 COVID-19, S. P. (2020). No Title. Covid19.Co.Id.

DIY, B. K. P. dan P. (2018). No Title. Bkpp.Jogjaprov.Go.Id. http://bkpp.jogjaprov.go.id/content/read/1045/ BKPP-DIY-Adakan-Temu-Gapoktan-bersama-Koppasindo

Dyah Mutiarin, M. (2021). New Public Management (New Public Comparison Meta-Analysis Developed and Developing Country Policies) Dyah. Journal of Government and Civil Society, 5(2), 145-163.

Gray, R. S. (2020). Agriculture, transportation, and the COVID-19 crisis. Canadian Journal of Agricultural Economics, 68(2), 239-243. https://doi.org/10.1111/cjag.12235

Ida Hanifah, Faisal, Zainuddin, Mhd. Teguh Syuhada lubis, Nur Alamsyah, Nurhilmiyah, Ida Nadirah, F., \& Faisal Riza, Nursariani Simatupang, Nurul Hakim, Andryan, R. (2016). "Seputar Hukum Di Indonesia ."

DPKP. (2020). No Title. DPKP.JOGJAPROV.GO.ID. https://dpkp.jogjaprov.go.id/baca/ DPKP+DIY+Menambah+50+Ton+Beras+Untuk+Cadangan+Pangan/151220/ fa4f15bf508f0fecca95053532f7cc3560b19dba17ce446e776d8f84f8f70de4261

Fuglsang, L., \& Pedersen, J. S. (2011). How Common Is Public Sector Innovation and How Similar Is It to Private Sector Innovation? In Innovation in the Public Sector. https://doi.org/10.1057/9780230307520_3

Kedaulatan Rakyat. (2020a). No Title. Core.Co.Id. https://www.core.co.id/2020/04/13/dampak-covid-19pariwisata-diy-rugi-rp-67-m/

Kedaulatan Rakyat. (2020b). No Title. Krjogja.Com. https://www.krjogja.com/berita-Lokal/diy/yogyakarta/ program-rumah-pangan-lestari-bakal-digencarkan/

Kumorotomo, W. (2019). No Title. Universitas Gadjah Mada. https://mkp.fisipol.ugm.ac.id/2019/11/19/ agile-government-pemerintahan-cergas/

News, A. (2020). No Title. Konsumsi Pangan Kota Yogyakarta Turun Hingga 50 Persen Akibat Pandemi. https://www.antaranews.com/berita/1606798/konsumsi-pangan-kota-yogyakarta-turun-hingga-50persen-akibat-pandemi

Purwanto, E. A. (2019a). Kebijakan Publik Yang Agile Dan Inovatif Dalam Memenangkan Persaingan Di Era Vuca (Volatile, Uncertain, Complex And Ambiguous). Molecules, 9(1), 148-162. http://jurnal. globalhealthsciencegroup.com/index.php/JPPP/article/download/83/65\%0Ahttp://www.embase.com/ search/results?subaction=viewrecord\&from=export\&id=L603546864\%5Cnhttp://dx.doi.org/10.1155/ 2015/420723\%0Ahttp://link.springer.com/10.1007/978-3-319-76

Purwanto, E. A. (2019b). No Title. Kebijakan Publik Yang Agile Dan Inovatif Dalam Memenangkan Persaingan Di Era Vuca. https://fisipol.ugm.ac.id/wp-content/uploads/sites/1056/2019/12/Pidato-GB-Erwan-AgusPurwanto-23-Des-2019-Cetak.pdf

Rosyadi, Sl., \& Indiahono, D. (2017). Administrasi publik new normal. In Universitas Brawijaya (Vol. 53, Issue 9).

Simatupang, P. (2016). Analisis Kritis terhadap Paradigma dan Kerangka Dasar Kebijakan Ketahanan Pangan Nasional. Forum Penelitian Agro Ekonomi, 25(1), 1. https://doi.org/10.21082/fae.v25n1.2007.1-18

Saliem, H. P., \& Ariani, M. (2016). Ketahanan Pangan, Konsep, Pengukuran dan Strategi. Forum Penelitian Agro Ekonomi, 20(1), 12. https://doi.org/10.21082/fae.v20n1.2002.12-24

Simatupang, P. (2007). A Critical Review on Paradigm and Framework of National Food Security Policy. Forum Penelitian AGRO EKONOMI, 25(1), 1-18. https://media.neliti.com/media/publications/70274ID-analisis-kritis-terhadap-paradigma-dan-k.pdf

Sofianto, A. (2020). Potensi Inovasi untuk Meningkatkan Kesejahteraan Masyarakat Desa. Matra Pembaruan, 4(2), 93-107. https://doi.org/10.21787/mp.4.2.2020.93-107

Suharyanto, H. (2011). KETAHANAN PANGAN Heri Suharyanto * Abstrak. Sosial Humaniora, 4(2), 186-194. http://dx.doi.org/10.12962/i24433527.v4i2.633 
Sumastuti, E. (2015). Jiwa Entrepreneurship Untuk Mewujudkan Ketahanan Pangan. Jiwa Entrepreneurship Untuk Mewujudkan Ketahanan Pangan, 3(1), 83-89. http://dx.doi.org/10.12962/j24433527.v4i2.633

Sururi, A. (2017). Inovasi Kebijakan dalam Perspektif Administrasi Publik Menuju Terwujudnya Good Public Policy Governance. 12, 14-31. https://doi.org/10.31227/osf.io/6djph

Syahyuti, Kariyasa, H. P. S. S. H. S. K., Ariningsih, S. H. S. Y. S. E., \& Indonesian. (2017). Temuan-Temuan Pokok Dan Rekomendasi Kebijakan Pembangunan Pertanian Dari Hasil-Hasil Penelitian Psekp Tahun 2014. In Journal of Chemical Information and Modeling (Vol. 110, Issue 9).

VOS, R., \& Cattaneo, A. (2021). Poverty reduction through the development of inclusive food value chains. Journal of Integrative Agriculture, 20(4), 964-978. https://doi.org/10.1016/S2095-3119(20)63398-6

Wicaksono, K. W. (2019). TIPOLOGI INOVASI SEKTOR PUBLIK PADA TIGA PROGRAM INOVATIF PEMERINTAH DAERAH KOTA SURABAYA (Tinjauan Reflektif terhadap Tiga Inovasi Pelayanan Publik Pemerintah Kota Surabaya Tahun 2018). Jurnal Manajemen Pelayanan Publik, 1(2), 196. https://doi. org/10.24198/jmpp.v1i2.19895

Yetrie Ludang, F. (2021). Sosialisasi Pencegahan Penyebaran Covid-19 Dan Pengembangan Ketahanan Pangan Di Kelurahan Sabaru Palangkaraya. Jurnal PengabdI, 4(2), 1-4. 